\title{
Privacy commissioner wants new criteria for entering health information in police database
}

$\mathrm{O}$ ntario's privacy commissioner is working with mental health and civil rights advocates to recommend changes to the health information entered and retained in a national police database that US border officials have used to deny some Canadians entry to the United States.

"What disturbs me is it appears that any call of an attempted suicide nature that is made to 911 and captured by the police is automatically shared with the RCMP [database]" says Ontario Information and Privacy Commissioner Ann Cavoukian. "It seems that this is the default position. That to me is unacceptable - completely unacceptable."

On Nov. 25, Ellen Richardson of Toronto, Ontario, was denied entry to the United States when she attempted to fly from Pearson International Airport to New York for a March of Dimes cruise. According to the Withdrawal of Application for Admission documents she received from US Customs and Border Protection, she was prohibited from entering the US because of "a medical episode" in June 2012 that a US official interpreted to mean she posed a risk to herself or others.

"RICHARDSON requires a Medical Evaluation for the mental illness episode to determine her clearance for travel to the United States," the document states.

Richardson was hospitalized in 2012 after she expressed suicidal thoughts and ideation, she says. Her mother called 911 to ask for an ambulance and for assistance to take her to hospital. (Richardson has paraplegia.) Richardson has since been treated, has recovered and was shocked to learn the information about that call was stored in a police database.

"It's outrageous," Richardson says. "It was evident to me that this particular customs officer did not have an adequate education and understanding about people with mental illness, that

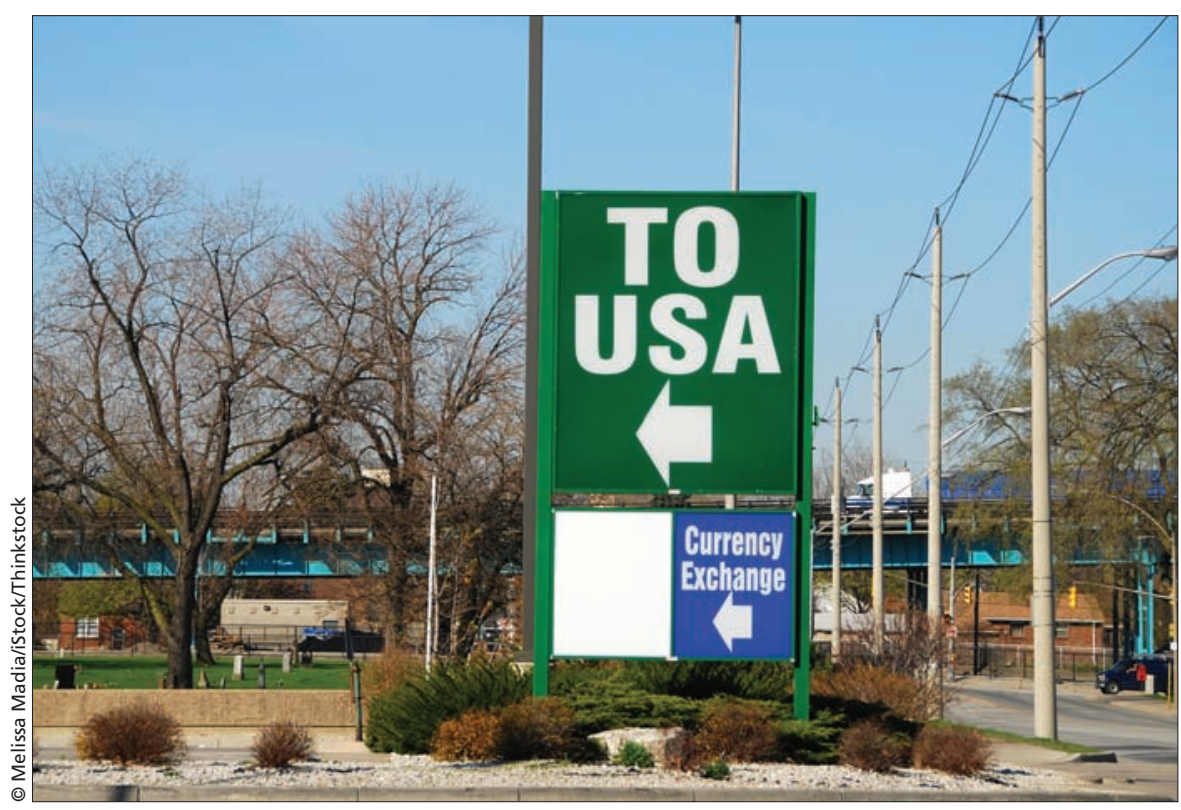

An Ontario woman was denied entry to the United States because of "a medical episode" in June 2012 that a US official interpreted to mean she posed a risk to herself or others.

they have periods of crisis but that they get better and become functional and productive once again. One episode should definitely not preclude me from going on vacation."

The border official would not call Richardson's psychiatrist, and referred her instead to one of three family doctors in the Toronto area authorized to conduct immigration exams.

Since Richardson made her case public, other Canadians who were also denied entry on the basis of mental health episodes have contacted her and reached out to Toronto MP Mike Sullivan to express their anger over the handling of their personal information.

The common denominator in the cases appears to be a call to 911 asking police for help when an individual was in crisis, says Sullivan. That information is automatically entered into the Canadian Police Information Centre (CPIC) database, which the RCMP manages.

"While we cannot discuss the details of an individual's processing due to the
Privacy Act, under U.S. immigration law ... applicants for admission bear the burden of proof to establish that they are clearly eligible to enter the United States," Michael Friel, media division director for US Customs and Border Protection, said in a written statement to CMAJ.

There are more than 60 grounds for inadmissibility to the US, including health-related grounds (and the everpopular miscellaneous grounds).

Originally, Canada's intent in allowing US officials access to CPIC was to provide the US Department of Homeland Security and Customs and Border Protection officials with information about people with criminal records, says Sullivan. US officials are apparently now using the information in a way it was not originally intended, and most Canadians aren't aware their country is providing that data to the US, Sullivan says.

"I think the CPIC database is being shared exactly as it exists with the US, 
even though there are supposed to be filters on it - the US is just seeing everything," says Sullivan. "Someone should be filtering what is shared across our border or with any agency that doesn't have a legitimate need to see it."

A spokesperson for the RCMP said the force was unable to comment on the conditions under which US officials can search CPIC.

Access to that law enforcement data is "critical" to the ability of Customs and Border Protection officials to protect public safety, one official with the US agency said in an interview. But it is rare that officials at ports of entry have to deal with circumstances involving information about mental health or attempted suicide, the official said.

Richardson's denial of entry raised the alarm among health and privacy advocates, including the Canadian Civil Liberties Association, the Psychiatric Patient Advocacy Office, the Canadian Mental Health Association and the Centre for Addiction and Mental
Health. Representatives of those organizations, as well as the Toronto Police Services Board and the Ontario Association of Chiefs of Police, will sit on an ad hoc committee Cavoukian has struck to draft new criteria for any health information entered and retained in the CPIC database, she says.

Interim Privacy Commissioner of Canada Chantal Bernier is also investigating Canada's role in sending Richardson's data to the US.

Although there may be rare instances where data involving an individual with a mental illness need to be entered into police databases, such as when the individual was brandishing a weapon, that should be the exception and not the rule, says Cavoukian.

In general, Canadian authorities should not be making the information in the CPIC database available to any US agency, she says. "If you really want to protect data, you don't make it available to anyone for potentially unauthorized use and disclosure - so that's my goal."
Richardson, Sullivan and Cavoukian say they are concerned that knowing this information is recorded and lingers in databases for years could prevent people who need help from calling 911 in the future.

"There are an awful lot of people in our country who are here because they left oppressive police states and who already have a fear of police," says Sullivan. "If phoning 911 gets you into a database that is then used years after the fact to deny you something, those people are going to be fearful about calling 911. The whole issue needs complete re-examination by all the levels of government who are involved in it."

Cavoukian hopes her committee will be able to develop criteria establishing when and why any such mental health information would be retained in any police database. "My hope is that this will be resolved early next year." Laura Eggertson, CMAJ

CMAJ 2014. DOI:10.1503/cmaj.109-4681 